\title{
Immune Response of Cattle Infected with African Trypanosomes
}

\author{
Katherine A Taylor ${ }^{+}$, Bea Mertens
}

\author{
International Livestock Research Institute, PO Box 30709, Nairobi, Kenya
}

\begin{abstract}
Trypanosomosis is the most economically important disease constraint to livestock productivity in sub-Saharan Africa and has significant negative impact in other parts of the world. Livestock are an integral component of farming systems and thus contribute significantly to food and economic security in developing countries. Current methods of control for trypanosomosis are inadequate to prevent the enormous socioeconomic losses resulting from this disease. A vaccine has been viewed as the most desirable control option. However, the complexity of the parasite's antigenic repertoire made development of a vaccine based on the variable surface glycoprotein coat unlikely. As a result, research is now focused on identifying invariant trypanosome components as potential targets for interrupting infection or infection-mediated disease. Immunosuppression appears to be a nearly universal feature of infection with African trypanosomes and thus may represent an essential element of the host-parasite relationship, possibly by reducing the host's ability to mount a protective immune response. Antibody, $T$ cell and macrophage/monocyte responses of infected cattle are depressed in both trypanosusceptible and trypanotolerant breeds of cattle. This review describes the specific $T$ cell and monocyte/macrophage functions that are altered in trypanosome-infected cattle and compares these disorders with those that have been described in the murine model of trypanosomosis. The identification of parasite factors that induce immunosuppression and the mechanisms that mediate depressed immune responses might suggest novel disease intervention strategies.
\end{abstract}

Key words: trypanosomosis - Trypanosoma congolense - bovine - immunodepression - T cell monocyte - cytokines

African trypanosomes are intravascular, extracellular parasites of livestock, humans and wild animals. Within the mammalian host, their cell membrane is covered by a variant surface glycoprotein (VSG) coat; termed variable because each parasite has an estimated 1000 VSG genes (Van der Ploeg et al. 1982), each encoding an antigenically distinct surface coat. Cattle immunized with irradiated trypanosomes or purified VSG are protected against a homologous (trypanosomes expressing the same antigenic repertoire), but not a heterologous, challenge (Wellde et al. 1975, Morrison et al. 1982). Thus, the potential of African trypanosomes to express different VSG coats reduces the likelihood of an effective VSG-based vaccine. As a result, vaccine design strategies are now focused on invariant trypanosome molecules that mediate pathogenesis (Authié 1994). It is clear that antigen selection and vaccine design will require knowledge of the immune responses provoked by infection and defini-

This is ILRI publication number 98056.

${ }^{+}$Corresponding author. Fax: 254-2-631499. E-mail: k.taylor@cgiar.org

Received 12 November 1998

Accepted 19 January 1999 tion of the mechanisms involved in either parasite or disease control.

Immunodepression is a well-documented feature of trypanosomosis in cattle, humans and mice (Mansfield 1989, De Baetselier 1996, Taylor 1998). There is evidence that infection-related immunodepression compromises the ability of animals to control trypanosomosis (Sternberg et al. 1994), as well as secondary infections (Scott et al. 1977, Rurangirwa et al. 1978). Therefore identification of host factors that induce immunodepression and the immune mechanisms involved might provide a rational approach for vaccine design aimed at improved disease control and thus increased livestock productivity.

The majority of research on African trypanosomosis has focused on murine infections with Trypanosoma brucei subsp. as models of human disease. In contrast, research on trypanosomosis of livestock has centred mainly on infections of cattle with $T$. congolense. Besides the obvious fact that murine and bovine hosts are immunologically distinct, it is important to remember that $T$. congolense and T. brucei subsp. are also biologically distinct. The most important difference may be that $T$. congolense is a strictly intravascular parasite, while infection with $T$. brucei subsp. has ex- 
travascular foci, particularly within the central nervous system. The sum effect of these differences limits the value of comparisons between the two experimental models. Nonetheless, research on trypanosomosis of livestock has often followed in the path of that on human trypanosomosis and thus comparisons can not be avoided.

\section{T CELL AND MONOCYTE/MACROPHAGE RE- SPONSES}

$\mathrm{T}$ cell proliferative responses are depressed during infection in both murine and bovine hosts. In mice, $T$ cell proliferation to mitogens and parasite antigens is either blocked or reduced. Reduced proliferative responses are associated with decreased interleukin-2 (IL-2) production and IL-2 receptor (IL-2R) expression in infected mice (Sileghem et al. 1986, 1987); nevertheless, cells retain the ability to secrete IFN-g (Sileghem et al. 1987, Bakhiet et al. 1990, Olsson et al. 1991, Schleifer et al. 1993). The mechanisms controlling $\mathrm{T}$ cell suppression in trypanosome-infected mice are not only site-specific, but also differ during the acute and chronic phases of infection (Beschin et al. 1998, Mabbott et al. 1998). In the lymph node, prostaglandins and nitric oxide secreted by activated macrophages inhibit IL-2 production (Sileghem et al. 1989b) and proliferation (Beschin et al. 1998), respectively, during the acute phase of infection in murine hosts. Decreased IL$2 \mathrm{R}$ expression is prostaglandin-independent and is reversed by anti-IFN-gantibodies (Darji et al. 1993, 1996), as is decreased proliferation (Beschin et al. 1998). In addition, the administration of anti-TNFa antibodies to infected mice partially restores $T$ cell proliferative responses in the lymph node (Darji et al. 1992). During the chronic stages of infection nitric oxide does not mediate $\mathrm{T}$ cell unresponsiveness in the lymph node; although IFN-gis involved, so are other factors that have not yet been identified (Beschin et al. 1998).

Both TNF-a and IFN-g are involved in increased secretion of macrophage-derived nitric oxide and prostaglandins in the peritoneal cavity and spleen of T. brucei- and T. b. rhodesiense-infected mice. These products in turn mediate $\mathrm{T}$ cell suppression (Sternberg \& Mc Guigan 1992, Schleifer \& Mansfield 1993), but apparently only during the very early days of infection (Beschin et al. 1998, Mabbott et al. 1998). The addition of nitric oxide- and prostaglandin-inhibitors to cells derived from the spleen and peritoneal cavity of $T$. b. rhodesiense-infected mice restored trypanosome antigen-specific and mitogen-triggered proliferation (Schleifer \& Mansfield 1993). Similarly, nitric oxide production was suppressed and proliferation was restored in cultures treated with antiIFN-g (Beschin et al. 1998) or anti-TNF-a mAb
(Darji et al. 1996), as well as in IFN-greceptor null mutant mice (Mabbott et al. 1998). Moreover, mice treated with a substrate analog inhibitor of nitric oxide controlled parasitaemia and anaemia better than untreated mice did (Sternberg et al. 1994, Mabbott \& Sternberg 1995). This suggests that the animals were capable of a more effective response if nitric oxide-mediated suppression was reversed. However, depressed $\mathrm{T}$ cell responses in the spleens of chronically infected mice are not sensitive to either nitric oxide inhibitors or anti-IFN- $g$ (Beschin et al. 1998, Mabbott et al. 1998). In addition, although $T . b$. rhodesiense-infected IFN-g receptor knock out mice controlled anaemia better over the first ten days of infection, these same mice experienced more severe anaemia than wild type mice later in infection (Mabbott et al. 1998).

Recent studies have suggested that TNF-a and IFN-gplay opposing roles in regulation of parasite growth. T. brucei release factors that induce murine CD8 T cells to secrete IFN-g, which was shown to be a parasite growth factor (Olsson et al. 1991). Similarly, T. brucei induces production of TNF-a, which, in contrast to IFN-g, has trypanolytic activity (Magez et al. 1993, 1997). However, it is not yet known how these cytokines interact in vivo to influence parasite numbers. The challenge now is to understand the contribution of these two cytokines to direct control of parasite numbers balanced with their influence on downstream immunological responses.

In summary, macrophages of trypanosome-infected mice produce immunosuppressive factors such as prostaglandins, nitric oxide, and TNF-a. During the early acute phase of infection these factors are involved in reduced $\mathrm{T}$ cell responses in the spleen and, to a lesser extent, the lymph node of $T$. bruce $i$ subsp.-infected mice. In addition, production of IFN-g by T cells appears to be a common feature in murine trypanosomosis. However, the factors that mediate suppressed $\mathrm{T}$ cell proliferative responses in chronically infected mice are not fully understood. More importantly, it is not clear how these responses relate to either protection or immunopathology.

In cattle, mitogen-induced proliferation, IL-2 production and IL-2R expression by cells derived from the lymph node draining the site of infection are transiently depressed (Flynn \& Sileghem 1991, Lutje et al. 1996, Taylor et al. 1996a). While trypanosome-specific proliferative responses can be detected in the draining lymph node during the second week of infection, they are not associated with significant IL-2 production and are nearly absent by one month post-infection (Lutje et al. 1995, 1996, Taylor et al. 1996a).

Efforts to characterise the regulation of IFN-g in $T$. congolense-infected cattle have been incon- 
clusive. While mitogen-induced IFN-gsecretion by lymph node cells was shown to increase in infected cattle (Sileghem \& Flynn 1992, Lutje et al. 1996), in another study, no significant change was detected (Taylor et al. 1996a). In addition, no increase in IFN-g mRNA is observed in lymph node or peripheral blood mononuclear cells (PBMCs) of infected cattle (Taylor et al. 1996a, 1998). Nonetheless, expression of IFN-gmRNA was higher in the spleen of two infected calves compared with their uninfected identical twin (Taylor et al. 1996a). These differences suggest that bovine trypanosomosis produces highly compartmentalized immune responses, similar to those seen in mice (De Baetselier 1996, Beschin et al. 1998).

Unlike those of the mouse, bovine monocyte and macrophage effector functions do not appear to be activated during trypanosomosis. Ex vivo secretion of TNF-a from monocytes of T. congolense-infected cattle is not increased, however, a small but transitory increase is observed in T. vivax-infected cattle (Sileghem et al. 1994). In keeping with this observation, TNF-a mRNA expression did not increase in the PBMC of T. congolense-infected cattle (Taylor et al. 1998, Mertens et al. 1999). Moreover, nitric oxide production is not elevated during infection of cattle and neither nitric oxide nor prostaglandins are responsible for reduced $\mathrm{T}$ cell proliferation of lymph node cells (Sileghem \& Flynn 1992, Taylor et al. 1996a).

More recent research suggests that IL-10, a macrophage de-activating cytokine, might be related to the apparent failure of monocytes and macrophages of trypanosome-infected cattle to produce inflammatory products. IL-10 mRNA transcripts are elevated in the peripheral blood, lymph node and splenic leukocytes of $T$. congolense-infected cattle (Taylor et al. 1996a, 1998). A pleuripotent cytokine, IL-10 is associated with $\mathrm{T}_{\mathrm{H}} 2$ type responses and can suppress macrophage effector and costimulatory functions (Moore et al. 1993).

IL-10 is known to suppresses the activation of inducible nitric oxide synthase, IL-1a, IL-6, TNFa and, possibly, IL-12, at the level of transcription in murine macrophages (deWaal Malefyt et al. 1991, Fiorentino et al. 1991, Kennedy et al. 1994). Coincident with the observed increase in IL-10 mRNA expression in PBMC, lymph node and spleen, monocytes of trypanosome-infected cattle became desensitised to IFN-g-induced secretion of nitric oxide (Taylor et al. 1996a, 1998). Furthermore, recombinant human IL-10 blocks both IFNg-induced nitric oxide and TNF-a production by monocytes derived from healthy cattle (Taylor et al. 1998). This, combined with the evidence that TNF-a production (Sileghem et al. 1994, Taylor et al. 1998, Mertens et al. 1999) does not increase during infection, suggests that macrophage monokines are not activated during bovine trypanosomosis and that IL-10 may be involved in this lack of response. Indeed, recent experiments have demonstrated that anti-IL-10 antibodies partially restored IFNg-induced nitric oxide production by monocytes derived from $T$. congolense-infected cattle (unpublished data).

IL-10 also acts to downregulate expression of the B7 costimulatory molecules on murine antigen-presenting cells (Willems et al. 1994), which may lead to $\mathrm{T}$ cell anergy and in some cases apoptosis (Dubois et al. 1994). Anergic T cells do not proliferate or produce IL-2, but retain the ability to produce other cytokines such as IFN-g (Jenkins et al. 1990). IL-10 has been associated with the induction of parasite antigen-specific $\mathrm{T}$ cell anergy in asymptomatic microfilaremic filariasis patients (King et al. 1993), schistosomiasis (King et al. 1996), leishmaniasis (Ghalib et al. 1993) and toxoplasmosis (Candolfi et al. 1995). Suppressed costimulatory signalling has also been proposed as the cause of anergy of $\mathrm{T}_{\mathrm{H}} 1$ cells that leads to apoptosis during HIV infection (Clerici et al. 1994) and leprosy (Sieling et al. 1993).

A number of observations are consistent with the loss of antigen-specific proliferation and IL-2 production in the lymph node of trypanosome-infected cattle arising from IL-10-mediated T cell anergy. First, the antigen-specific hypo-responsiveness of lymph node cells is preceded by a period of responsiveness, at which time IL-10 mRNA transcripts are normal (Taylor et al. 1996a, 1998). Second, that $\mathrm{T}$ cell suppression in the lymph nodes of infected cattle is related to suppression of macrophage accessory cell function is consistent with the finding that "macrophage-like" cells are responsible for depressed mitogen-triggered proliferation of lymph node cells (Flynn \& Sileghem 1991). Third, recombinant human IL-10 suppresses proliferation of antigen-specific bovine $\mathrm{T}$ cell clones and down-regulates expression of IL-2R and IFNgmRNA (Chitko-McKown et al. 1995). Interestingly, BALB/c mice, which are highly trypanosusceptible, produce significantly more IL-10 when infected with $T$. congolense than relatively trypanoresistant C57B1/6 mice. Addition of antiIL-10 antibodies in cultures of mitogen-stimulated spleen cells from infected mice completely restored proliferation (Uzonna et al. 1998). In this study, $\mathrm{BALB} / \mathrm{c}$ mice treated with anti-IL-10 antibodies and infected with $T$. congolense exhibited slightly longer survival times than untreated mice. Efforts are currently underway to test the role of IL-10 in mitogen and antigen-specific $T$ cell responses during trypanosomosis in cattle directly.

There is conflicting evidence regarding the integrity of macrophage costimulatory functions during murine trypanosomosis. IL-1 secretion and 
antigen-presentation function are depressed in $T$. b. rhodesiense-infected mice (Paulnock et al. 1988) and in both resistant and susceptible strains of $T$. congolense-infected mice (Mitchell et al. 1986). Similarly, $\mathrm{Ia}^{+}$macrophages are depleted during murine T. b. rhodesiense infection (Bagasra et al. 1981). No increase in IL-1 mRNA transcription was observed in the PBMC of T. congolense-infected trypanotolerant or trypanosusceptible cattle (Mertens et al. 1999), again suggesting that costimulatory functions are not elevated. It should be noted, however, that increased IL-1 production was observed in T. brucei-infected mice (Sileghem et al. 1989a).

Analysis of cytokine mRNA expression confirms that neither $\mathrm{T}_{\mathrm{H}} 1$ cytokines nor inflammatory monokines are increased during $T$. congolense infection of either trypanosusceptible or trypanotolerant cattle (Mertens et al. 1999). However, transcription of the $\mathrm{T}_{\mathrm{H}} 2$ type cytokine IL-4 was increased in trypanotolerant cattle, but not trypanosusceptible cattle, one month post-infection (Mertens et al. 1999). As IL-4 is an important regulatory molecule for isotype switching from IgM to IgG1 (Estes 1996), perhaps it is not coincidental that trypanotolerant cattle produce more $\mathrm{IgG} 1$ to a number of trypanosome antigens than do trypanosusceptible cattle (Taylor et al. 1996b).

\section{CONCLUSIONS}

A crucial question is whether depressed macrophage and $\mathrm{T}$ cell responses tip the balance of infection in favour of the host or the parasite during bovine trypanosomosis. Down-regulation of monokines and other $\mathrm{T}_{\mathrm{H}} 1$ type cytokines by IL-10 has been shown to protect against immunopathology in mice infected with a variety of parasites (Flores-Villanuveva et al. 1996, Gazzinelli et al. 1996) but can also lead to ineffective parasite killing (Heinzel et al. 1991, Silva et al. 1992, Gazzinelli et al. 1992). In this context, it is important to recognise the distinction between trypanotolerant and trypanosusceptible cattle. Trypanotolerant breeds of cattle are not refractory to infection. In fact, they are just as "susceptible" to primary infection as so-called trypanosusceptible breeds. There is little or no difference in parasitaemia between trypanotolerant and trypanosusceptible cattle during the early stages of infection. Despite this, trypanotolerant cattle maintain higher packed-cell volumes throughout infection and eventually control parasite numbers during the chronic stages of infection (Paling et al. 1991a, b). That antigen-specific and mitogen-driven $T$ cell responses appear to be equally depressed in both trypanotolerant and trypanosusceptible breeds of cattle, suggests that these responses are not required to control disease.
However, loss of these responses may be necessary for the successful establishment of parasites, as well as their continued presence, in both the acutely- and chronically-infected animal. In contrast, specific antibody responses and an upregulation of IL-4 in trypanotolerant cattle may be involved in these animals ability to control disease, despite the presence of parasites.

Our laboratory is currently devoted to understanding the role of IL-4 and isotype switching in trypanotolerance. In addition, efforts to determine the contribution of depressed $\mathrm{T}_{\mathrm{H}} 1$ and macrophage effector functions to the establishment and maintenance of infection continue. Development of improved strategies for the control of trypanosomosis will depend heavily on an understanding of the balance between protective and pathogenic immune responses in the face of infection.

\section{REFERENCES}

Authié E 1994. Trypanosomiasis and trypanotolerance: a role for congopain? Parasitol Today 10: 360-364.

Bagasra O, Schell RF, Le Frock JL 1981. Evidence for depletion of $\mathrm{Ia}^{+}$macrophages and associated immunosuppression in African trypanosomiasis. Infect Immun 32: 188-193.

Bakhiet M, Olsson T, Van der Meide P, Kristensson K 1990. Depletion of CD8+ T cells suppresses growth of Trypanosoma brucei bruce $i$ and interferon-gamma production in infected rats. Clin Exp Immunol 81: 195-199.

Beschin A, Brys L, Magez S, Radwanska M, De Baetselier P 1998. Trypanosoma brucei infection elicits nitric oxide-dependent and nitric oxide-independent suppressive mechanisms. J Leuk Biol 63: 429-439.

Candolfi E, Hunter CA, Remington JS 1995. Roles of gamma interferon and other cytokines in suppression of the spleen cell proliferative response to concanavalin A and toxoplasma antigen during acute toxoplasmosis. Infect Immun 63: 751-756.

Chitko-McKown CG, Ruef BJ, Rice-Ficht AC, Brown WC 1995. Interleukin-10 downregulates proliferation and expression of interleukin-2 receptor p55 chain and interferon-g, but not interleukin- 2 or interleukin-4, by parasite-specific helper $\mathrm{T}$ cell clones obtained from cattle chronically infected with Babesia bovis or Fasciola hepatica. J Interferon Cytokine Res 15: 915-922.

Clerici M, Wynn TA, Berzofsky JA, Blatt SP, Hendrix CW, Sher A, Coffman RL, Shearer GM 1994. Role of interleukin-10 in T helper cell dysfunction in asymptomatic individuals infected with the human immunodeficiency virus. J Clin Invest 93: 768-75.

Darji A, Beschin A, Sileghem M, Heremans H, Brys L, De Baetselier P 1996. In vitro stimulation of immunosuppression caused by Trypanosoma brucei: active involvement of gamma interferon and tumor necrosis factor in the pathway of suppression. Infect Immun 64: 1937-1943.

Darji A, Lucas R, Magez S, Torreele E, Palacios J, Sileghem M, Bajyana Songa E, Hamers R, De 
Baetselier P 1992. Mechanisms underlying trypanosome-elicited immunosuppression. Ann Soc Belge Med Trop 72: 27-38.

Darji A, Sileghem M, Heremans H, Brys L, De Baetselier $\mathrm{P}$ 1993. Inhibition of T-cell responsiveness during experimental infections with Trypanosoma brucei: active involvement of endogenous gamma interferon. Infect Immun 61: 3098-3102.

De Baetselier P 1996. Mechanisms underlying trypanosome-induced T-cell immunosuppression, p. 124139. In AS Mustafa, RJ Al-Attiyah, I Nath, TD Chugh, (eds), T-Cell Subsets and Cytokines Interplay in Infectious Diseases, S Karger, Basel, Switzerland.

de Waal Malefyt R, Abrams J, Bennett B, Figdor CG, de Vries JE 1991. Interleukin 10 (IL-10) inhibits cytokine synthesis by human monocytes: an autoregulatory role of IL-10 produced by monocytes. $J$ Exp Med 174: 1209-1220.

Dubois PM, Andris F, Shapiro RA, Gilliland LK, Kaufman M, Urbain J, Ledbetter JA, Leo O 1994. $\mathrm{T}$ cell long-term hyporesponsiveness follows antigen receptor engagement and results from defective signal transduction. Eur J Immunol 24: 348-354.

Estes M 1996. Differentiation of B cells in the bovine. Role of cytokines in immunoglobulin isotype expression. Vet Immunol Immunopathol 54: 61-67.

Fiorentino DF, Zlotnik A, Mossman TR, Howard M, O'Garra A 1991. IL-10 inhibits cytokine production by activated macrophages. J Immunol 147: 38153822.

Flores-Villanueva PW, Zheng XX, Strom TB, Stadecker JJ 1996. Recombinant IL-10 and IL-10/Fc treatment down-regulate egg antigen-specific delayed hypersensitivity reactions and egg granuloma formation in schistosomiasis. J Immunol 156: 3315-3320.

Flynn JN, Sileghem M 1991. The role of the macrophage in induction of immunosuppression in Trypanosoma congolense-infected cattle. Immunology 74 : 310-316.

Gazzinelli RT, Oswald IP, James S L, Sher A 1992. IL10 inhibits parasite killing and nitrogen oxide production by IFN-g-activated macrophages. J Immunol 148: 1792-1796.

Gazzinelli RT, Wysocka M, Hieny S, Scharton-Kersten T, Cheever A, Kuhn R, Muller W, Trinchiere G, Sher A 1996. In the absence of endogenous IL-10, mice acutely infected with Toxoplasma gondii succumb to a lethal immune response dependent on $\mathrm{CD} 4^{+} \mathrm{T}$ cells and accompanied by overproduction of IL-12, IFN-g, and TNF-a. J Immunol 157: 798-805.

Ghalib HW, Piuvezam MR, Skeiky YA, Siddig M, Hashim FA, el Hassan AM, Russo DM, Reed SG 1993. Interleukin 10 production correlates with pathology in human Leishmania donovani. J Clin Invest 92: 324-329.

Heinzel FP, Sadick MD, Mutha SS, Locksley RM 1991. Production of interferon-gamma, interleukin 2, interleukin 10 by $\mathrm{CD}^{+}$lymphocytes in vivo during healing and progressive murine leishmaniasis. Proc Natl Acad Sci USA 88: 7011-7015.

Jenkins MJ, Chen C, Jung G, Mueller DL, Schwartz RH 1990. Inhibition of antigen-specific proliferation of Type 1 murine $\mathrm{T}$ cell clones after stimulation with immobilized anti-CD3 monoclonal antibody. $J$ Immunol 140: 16-22.

Kennedy MK, Picha KS, Shaneveck KD, Anderson DM, Grabstein KH 1994. Interleukin-12 regulates the proliferation of Th1, but not Th2 or Th0, clones. Eur J Immunol 24: 2271-2278.

King CL, Mahanty S, Kumaraswami V, Abrams JS, Regunathan J, Jayarman K, Ottesen EA, Nutman TB 1993. Cytokine control of parasite-specific anergy in human lymphatic filariasis. J Clin Invest 92: 16671673.

King CL, Medhat A, Malhotra I, Nafeh M, Khaudary J, Ibrahim S, El-Sherbiny M, Zaky S, Stupi RJ, Brustoski K, Shehata M, Shata MT 1996. Cytokine control of parasite-specific anergy in human urinary schistosomiasis, IL-10 modulates lymphocyte reactivity. J Immunol 156: 4715-4721.

Lutje V, Mertens B, Boulangé A, Williams DJL, Authié E 1995. Trypanosoma congolense: proliferative responses and interleukin production in lymph node cells of infected cattle. Exp Parasitol 81: 154-164.

Lutje V, Taylor KA, Kennedy D, Authié E, Boulangé A, Gettinby G 1996. Trypanosoma congolense: a comparison of T-cell-mediated responses in lymph nodes of trypanotolerant and trypanosusceptible cattle during primary infection. Exp Parasitol 84: 320-329.

Mabbott N, Sternberg J 1995. Bone marrow nitric oxide production and development of anemia in Trypanosoma brucei-infected mice. Infect Immun 63: 15631566.

Mabbott NA, Coulson PS, Smythies LE, Wilson RA, Sternberg J 1998. African trypanosome infections in mice that lack the interferon-greceptor gene: nitric oxide-dependent and independent suppression of T-cell proliferative responses and the development of anaemia. Immunology 94: 476-480.

Magez S, Geuskens M, Beschin A, del Favero H, Verschueren H, Lucas R, Pays E, De Baetselier P 1997. Specific uptake of tumor necrosis factor-a is involved in growth control of Trypanosoma brucei. J. Cell Biol. 137: 715-727.

Magez S, Lucas R, Darji A, Songa EB, Hamers R, De Baetselier P 1993. Murine tumour necrosis factor plays a protective role during the initial phase of the experimental infection with Trypanosoma brucei brucei. Parasite Immunol 15: 635-641.

Mansfield JM 1989. Immunology of African trypanosomiasis, p. 222-246. In DG Wyler, Modern Parasite Biology, WH Freeman and Company, New York.

Mertens B, Taylor K, Muriuki C, Rocchi M 1999. Cytokine mRNA profiles in trypanotolerant and trypanosusceptible cattle infected with the protozoan parasite Trypanosoma congolense: protective role for IL-4? J Interferon Cytokine Res 19: in press.

Mitchell LA, Pearson TW, Gauldie J 1986. Interleukin1 and interleukin-2 production in resistant and susceptible inbred mice infected with Trypanosoma congolense. Immunology 57: 291-296.

Moore KW, O'Garra A, de Waal Malefyt R, Vieira P, Mossman TR 1993. Interleukin-10. Ann Rev Immunol 11: 165-190.

Morrison WI, Black SJ, Paris J, Hinson CA, Wells PW 1982. Protective immunity and specificity of antibody responses elicited in cattle by irradiated Try- 
panosoma brucei. Parasite Immunol 4: 395-407.

Olsson T, Bakhiet M, Edlund C, Höjeberg B, Van der Meide PH, Kristensson K 1991. Bi-directional activating signals between Trypanosoma brucei and $\mathrm{CD}^{+} \mathrm{T}$ cells: a trypanosome-released factor triggers interferon-gproduction that stimulates parasite growth. Eur J Immunol 21: 2447-2454.

Paling RW, Moloo SK, Scott JR, McOdimba FA, Logan-Henfrey LL, Murray M. Williams DJL 1991a. Susceptibility of N'Dama and Boran cattle to tsetsetransmitted primary and rechallenge infections with a homologous serodeme of Trypanosoma congolense. Parasite Immunol 13: 413-425.

Paling RW, Moloo SK, Scott JR, Gettinby G, McOdimba FA, Murray M 1991b. Susceptibility of N'Dama and Boran cattle to sequential challenges with tsetsetransmitted clones of Trypanosoma congolense. Parasite Immunol 13: 427-445.

Paulnock CM, Smith C, Mansfield JM 1988. Antigen presenting cell function in African trypanosomiasis, p. 135-143. In LB Schook \& JG Tew (eds), Antigen Presenting Cells: Diversity, Differentiation, and Regulation, Alan R Liss Inc.

Rurangirwa RR, Tabel H, Losos G, Masiga WN, Mwambu P 1978. Immunosuppressive effects of Trypanosoma congolense and Trypansoma vivax on the secondary immune response of cattle to $\mathrm{Myco}$ plasma mycoides subsp. mycoides. Res Vet Sci 25: 395-397.

Schleifer KW, Mansfield JM 1993. Suppressor macrophages in African trypanosomiasis inhibit T cell proliferative responses by nitric oxide and prostaglandins. J Immunol 151: 5492-5503.

Schleifer KW, Filutowicz H, Schopf LR, Mansfield JM. 1993. Characterization of T helper cell responses to the trypanosome variant surface glycoprotein. $J$ Immunol 150: 2910-2919.

Scott JM, Pegram G, Holmes PH, Pay TWF, Knight PA, Jennings FW, Urquhart GM 1977. Immunosuppression in bovine trypanosomiasis: field studies using foot-and-mouth disease vaccine and clostridial vaccine. Trop Anim Hlth Prod 9: 159-165.

Sileghem M, Flynn JN 1992. Suppression of T-cell responsiveness during tsetse-transmitted trypanosomiasis in cattle. Scand J Immunol 36 (Suppl 11): 37-40.

Sieling PA, Abrams JS, Yamamura M, Salgame P, Bloom BR, Rea TH, Modlin RL 1993. Immunosuppressive roles for IL-10 and IL-4 in human infection. $J$ Immunol 150: 5501-5510.

Sileghem M, Darji A, Hamers R, De Baetselier P 1989a. Modulation of IL-1 production and IL-1 release during experimental trypanosome infections. Immunology 68: 137-139.

Sileghem M, Darji A, Remels L, Hamers R, De Baetselier P 1989b. Different mechanisms account for the suppression of interleukin-2 production and the suppression of interleukin-2 receptor expression in Trypanosoma brucei-infected mice. Eur J Immunol 19: 825-835.

Sileghem M, Flynn JN, Logan-Henfrey L, Ellis J 1994. Tumor necrosis factor production by monocytes from cattle infected with Trypanosoma (Duttonella) vivax and Trypanosoma (Nannomonas) congolense: pos- sible association with severity of anaemia associated with the disease. Parasite Immunol 16: 51-54.

Sileghem M, Hamers R, De Baetselier P 1986. Active suppression of interleukin-2 secretion in mice infected with Trypanosoma brucei AnTat 1.1E. Parasite Immunol 8: 641-649.

Sileghem M, Hamers R, De Baetselier P 1987. Experimental Trypanosoma brucei infection selectively suppress both interleukin 2 production and interleukin-2 receptor expression. Eur J Immunol 17: 1417-1421.

Silva JS, Morrissey PJ, Grabstein KH, Mohler KM, Anderson D, Reed SG 1992. Interleukin 10 and interferon gregulation of experimental Trypanosoma cruzi infection. J Exp Med 175: 169-174.

Sternberg J, McGuigan F 1992. Nitric oxide mediates suppression of $\mathrm{T}$ cell responses in murine Trypanosoma brucei infection. Eur J Immunol 22: 2741-2744.

Sternberg J, Mabbott N, Sutherland I, Liew FY 1994. Inhibition of nitric oxide synthesis leads to reduced parasitemia in murine Trypanosoma brucei infection. Infect Immun 62: 2135-2137.

Taylor KA 1998. Immune responses of cattle to African trypanosomes: protective or pathogenic? Intl J Parasitol 28: 219-240.

Taylor KA, Lutje V, Mertens B 1996a. Nitric oxide synthesis is depressed in Bos indicus cattle infected with Trypanosoma congolense and T. vivax and does not mediate T cell suppression. Infect Immun 64: 41154122.

Taylor KA, Lutje V, Kennedy D, Authié E, Boulangé A, Logan-Henfrey L, Gichuki B, Gettinbly G 1996b. Trypanosoma congolense: B-lymphocyte responses differ between trypanotolerant and trypanosusceptible cattle. Exp Parasitol 83: 106-116.

Taylor KA, Mertens B, Lutje V, Saya R 1998. Trypanosoma congolense infection of trypanotolerant N'Dama (Bos taurus) cattle is associated with decreased secretion of nitric oxide by interferon-g-activated monocytes and increased transcription of interleukin-10. Parasite Immunol 20: 421-429.

Uzonna JE, Kaushik RS, Gordon JR, Tabel H 1998. Immunoregulation in experimental murine Trypanosoma congolense infection: anti-IL-10 antibodies reverse trypanosome-mediated suppression of lymphocyte proliferation in vitro and moderately prolong the lifespan of genetically susceptible BALB/c mice. Parasite Immunol 20: 293-302.

Van der Ploeg LHT, Valerio C, De Lange T, Bernards A, Borst P, Grosveld FG 1982. An analysis of cosmid clones of nuclear DNA from Trypanosoma brucei shows that the genes for variant surface glycoproteins are clustered in the genome. Nucleic Acids Res 10: 5905-5923.

Wellde BT, Schoebeckler MJ, Diggs CL, Langbelin HR, Sadun EH 1975. Trypanosoma rhodesiense: variant specificity of immunity induced by irradiated parasites. Exp Parasitol 37: 125-129.

Willems F, Marchant A, Delville JP, Gerard C, Delvaux A, Velu T, de Boer M, Goldman M 1994. Interleukin10 inhibits B7 and intercellular adhesion molecule1 expression on human monocytes. Eur J Immunol 24: 1007-1009. 